\title{
Heat loss from the Atlantic water layer in the northern Kara Sea: causes and consequences
}

\author{
I. A. Dmitrenko ${ }^{1}$, S. A. Kirillov ${ }^{1}$, N. Serra ${ }^{2}$, N. V. Koldunov ${ }^{2}$, V. V. Ivanov $^{3,4}$, U. Schauer ${ }^{5}$, I. V. Polyakov ${ }^{4}$, D. Barber ${ }^{1}$, \\ M. Janout ${ }^{5}$, V. S. Lien ${ }^{6}$, M. Makhotin ${ }^{3}$, and Y. Aksenov ${ }^{7}$ \\ ${ }^{1}$ Centre for Earth Observation Science, University of Manitoba, Winnipeg, Canada \\ ${ }^{2}$ Institute of Oceanography, University of Hamburg, Hamburg, Germany \\ ${ }^{3}$ Arctic and Antarctic Research Institute, St. Petersburg, Russia \\ ${ }^{4}$ International Arctic Research Center, University of Alaska Fairbanks, Fairbanks, AK, USA \\ ${ }^{5}$ Alfred Wegener Institute for Polar and Marine Research, Bremerhaven, Germany \\ ${ }^{6}$ Institute of Marine Research, Bergen, Norway \\ ${ }^{7}$ National Oceanography Centre Southampton, Southampton, UK
}

Dedicated to the memory of our colleague Klaus Hochheim, who tragically lost his life in the Arctic expedition in September 2013

Correspondence to: I. A. Dmitrenko (igor.dmitrenko@umanitoba.ca)

Received: 15 January 2014 - Published in Ocean Sci. Discuss.: 20 February 2014

Revised: 16 June 2014 - Accepted: 7 July 2014 - Published: 15 August 2014

\begin{abstract}
A distinct, subsurface density front along the eastern St. Anna Trough in the northern Kara Sea is inferred from hydrographic observations in 1996 and 2008-2010. Direct velocity measurements show a persistent northward subsurface current $\left(\sim 18 \mathrm{~cm} \mathrm{~s}^{-1}\right)$ along the St. Anna Trough eastern flank. This sheared flow, carrying the outflow from the Barents and Kara seas to the Arctic Ocean, is also evident from shipboard observations as well as from geostrophic velocities and numerical model simulations. Although we cannot substantiate our conclusions by direct observation-based estimates of mixing rates in the area, we hypothesize that the enhanced vertical mixing along the St. Anna Trough eastern flank favors the upward heat loss from the intermediate warm Atlantic water layer. Modeling results support this hypothesis. The upward heat flux inferred from hydrographic data and model simulations is of $O(30-100) \mathrm{W} \mathrm{m}^{-2}$. The region of lowered sea ice thickness and concentration seen both in sea ice remote sensing observations and model simulations marks the Atlantic water pathway in the St. Anna Trough and adjacent Nansen Basin continental margin. In fact, the sea ice shows a delayed freeze-up onset during fall and a reduction in the sea ice thickness during winter. This is consistent with our results on the enhanced Atlantic water heat loss along the Atlantic water pathway in the St. Anna Trough.
\end{abstract}

\section{Introduction}

The warm Atlantic water (AW) plays a role in reducing the sea-ice cover in the Northern Hemisphere through upward heat loss (Polyakov et al., 2010). The AW heat loss impacts the ice cover along the Arctic Ocean Eurasian continental margins (Polyakov et al., 2010), but is significantly stronger over the regions of the AW inflow into the Arctic Ocean through the Fram Strait (the Fram Strait branch of AW inflow - FSBW) and in the Barents Sea (the Barents Sea branch of AW inflow - BSBW). These are areas where the inflowing AW with temperatures $T \sim 5^{\circ} \mathrm{C}$ occupies the surface layer, directly affecting the ocean-sea-ice-atmosphere interface (Sirevaag and Fer, 2009; Årthun et al., 2012; Ivanov et al., 2012). Over the last decades, observations indicate an increase of AW transport into the Arctic through the Barents Sea (e.g., Skagseth et al., 2008), which impacts the observed sea ice reduction (e.g., Schlichtholz, 2011; Arthun et al., 2012). The AW transport into the Arctic through the Fram Strait shows similar patterns and impacts (e.g., Ivanov et al., 2012; Alexeev et al., 2013). Model simulations of future projections show analogous regularities (e.g., Koenigk and Brodeau, 2013). 
While transiting along the continental slope of Svalbard (red arrows in Fig. 1) and through the Barents Sea (blue arrows in Fig. 1), the AW gradually cools and deepens, becoming isolated from the surface. In the area of the St. Anna Trough (hereinafter ST) in the northern Kara Sea, the submerged BSBW with temperatures slightly above $0{ }^{\circ} \mathrm{C}$ merges with a fraction of the warm intermediate FSBW $(T \sim 2.0$ $2.5^{\circ} \mathrm{C}$ ), which enters the western ST steered by the topography (Hanzlick and Aagaard, 1980; Schauer et al., 2002a) Figs. 1 and 2. Hereafter we refer to this fraction of the FSBW as ST-circulating FSBW (SFSBW).

The SFSBW return flow to the Arctic Ocean along the ST eastern slope is colder and less saline than the FSBW (Schauer et al., 2002b), which indicates mixing and heat loss along the SFSBW pathway in the ST, as suggested by Hanzlick and Aagaard (1980). This allows speculations that a fraction of the SFSBW heat is released upwards with potential implication for the ocean-sea-ice-atmosphere interface. This paper addresses the issue of SFSBW modification in the ST with a special focus on water dynamics and mixing occurring along the ST eastern flank. We suggest that vertical mixing promoted by the interaction of the SFSBW with the Barents and Kara seas outflow can favor an enhanced AW heat loss, resulting in a consistent delay of freeze-up onset in fall, sea ice thinning in winter, and earlier spring retreat.

\section{Data and methods}

Oceanographic CTD transects across the ST (Fig. 2) were taken from the icebreaker Kapitan Dranitsyn along $\sim 81^{\circ} \mathrm{N}$ (24 October 2008) and along $\sim 81$ and $82^{\circ} \mathrm{N}(22-23 \mathrm{Au}-$ gust 2009 and 2-3 September 2009, respectively), and from the RV Nikolay Evgenov along $\sim 81^{\circ} \mathrm{N}$ (22 September 2010). These sections were sampled using a shipboard SBE19 + CTD (in 2009-2010) and Lockheed Martin Sippican Expendable Bathythermographs - XBTs and Expendable Conductivity, Temperature, and Depth Profilers - XCTDs (in 2008). These data were complemented by oceanographic stations occupied across the ST along $\sim 82^{\circ} \mathrm{N}$ in July 1996 during the ARKXII cruise of the RV Polarstern (Schauer et al., 2002b). In addition, we used the velocity data collected from a conventional mooring equipped with Teledyne RD Instruments $300 \mathrm{kHz}$ Workhorse Sentinel Acoustic Doppler Current Profilers (ADCPs) measuring velocity through the depth range of $134-218 \mathrm{~m}$ and 376-468 m from 24 August 2009 to 22 September 2010. The mooring was deployed at the eastern slope of the ST at $81^{\circ} 01^{\prime} \mathrm{N}, 73^{\circ} 02^{\prime} \mathrm{E}$ (Fig. 2) in $\sim 520 \mathrm{~m}$ water depth.

We use gridded satellite data of ice concentration (from the Integrated Climate Data Center at the University of Hamburg, Germany), ice thickness (from the Jet Propulsion Laboratory, USA), and ice drift (from the Center IFREMER of Brest, France). The sea ice concentration is derived from the Advanced Microwave Scanning Radiometer for EOS -

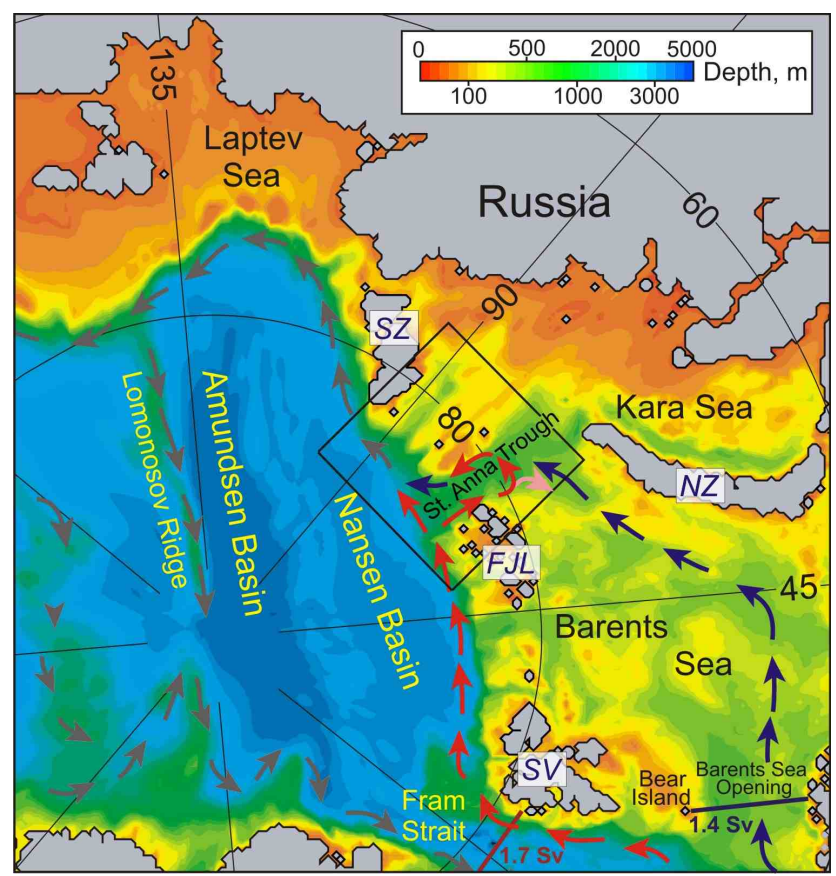

Figure 1. Map of the inflow region of Atlantic water (AW) to the Arctic Ocean. Arrows trace the Atlantic water (AW) pathways; red and blue arrows show the Fram Strait and Barents Sea branches, respectively, of the AW inflow into the Arctic Ocean in accordance with Rudels et al. (1994). The pink arrow shows a fraction of the Fram Strait branch water flowing west along the shallower trough between Novaya Zemlya and Franz Josef Land. Dark red and blue numbered lines in Fram Strait and Barents Sea Opening, respectively, show sections used for verifying the simulated volume transport of AW. Dark blue number indicates the simulated volume transport of AW (defined as $T>3^{\circ} \mathrm{C}$ ) through the Barents Sea Opening. Dark red number shows the simulated volume transport of AW (defined as $T>2{ }^{\circ} \mathrm{C}$ ) in the core of the West Spitsbergen Current. The black rectangle encloses the region enlarged in Fig. 2. SV - Svalbard, FJL - Franz Josef Land, NZ - Novaya Zemlya, SZ - Severnaya Zemlya.

AMSR-E (2005-2010) and Special Sensor Microwave Imager/Sounder - SSMIS (2011) (Spreen et al., 2008). The sea ice thickness is from the Ice, Cloud, and land Elevation Satellite (ICESat) (Kwok et al., 2009). The sea-ice drift is derived from the $89 \mathrm{GHz}$ brightness temperature of the AMSR (Ezraty et al., 2007). The spatial grid resolution for ice concentration, thickness and drift is $6.25,25$ and $31.25 \mathrm{~km}$, respectively. According to Kwok and Cunningham (2008), the uncertainty of the ICESat sea ice thickness is $\sim 0.5 \mathrm{~m}$ based on the assessment with data from submarines and upwardlooking sonars. Comparisons of the satellite derived sea ice drift data with buoys for a 3-day period show almost no bias; however, the standard deviation for the ice drift velocity and direction is $6.7 \mathrm{~km}$ and $35^{\circ}$, respectively (Ezraty et al., 2007). Although the uncertainty of individual scans of satellite measurements is large, the spatial and temporal 


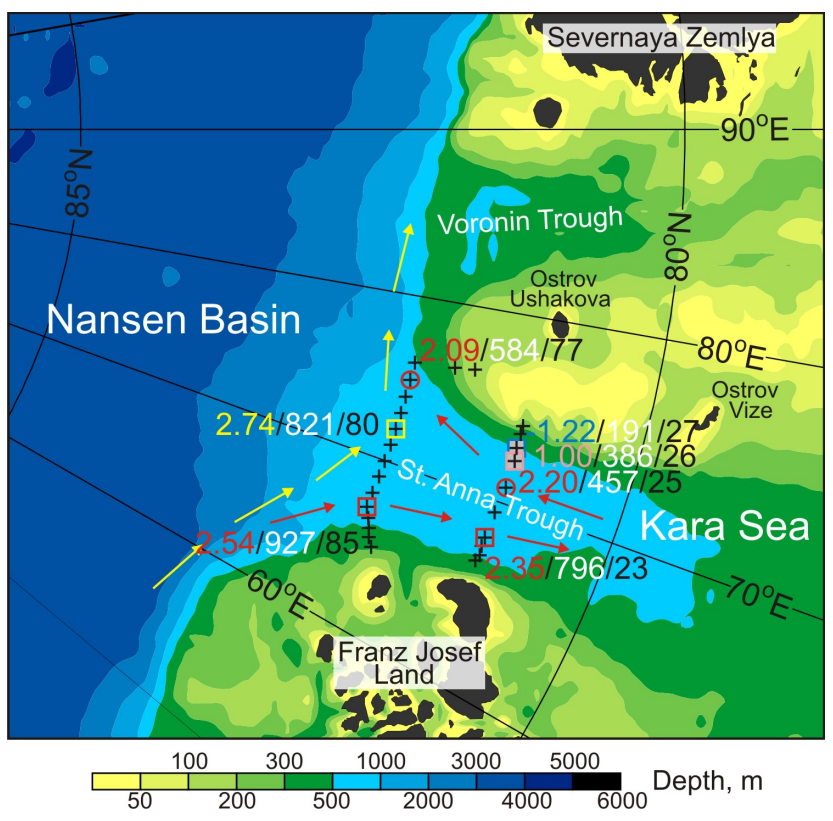

Figure 2. Map of the northern Kara Sea showing the St. Anna Trough (ST). Arrows show the Fram Strait branch of the AW inflow into the Arctic Ocean, which recirculates in the ST (red arrows, SFSBW) and follows the continental margin (yellow arrows, FSBW). Crosses depict the positions of CTD stations taken in September 2009 at two sections crossing the ST at $\sim 81$ and $82^{\circ} \mathrm{N}$. Red squares and circles identify stations taken through the core of the SFSBW inflow and outflow to/from the ST, respectively. The yellow square identifies a station taken through the core of the FSBW boundary current. The pink square depicts the mooring position. The pink and blue squares with gray shading identify stations used for estimates of uncertainty in the vertical heat flux due to spatial undersampling of the AW jet. The first (yellow/red) number shows the FSBW/SFSBW core temperature (in ${ }^{\circ} \mathrm{C}$ ) in September 2009. The first pink and blue numbers show temperature at $110 \mathrm{~m}$. The second (white) number is heat content (in $\mathrm{MJ} \mathrm{m}^{-2}$ ) computed relative to the freezing temperature between 30 to $90 \mathrm{~m}$ depth. The third (black) number denotes the station number.

averaging reduces the associated errors down to about $5 \mathrm{~cm}$ and $0.07 \mathrm{~km} \mathrm{day}^{-1}$ for the sea thickness and drift, respectively. The surface air temperature for the ST area used here is from the National Centers for Environmental Prediction (NCEP) reanalysis (Kalnay et al., 1996).

In this study we further use ocean velocity, sea ice thickness and concentration, and vertical heat fluxes simulated with the coupled ocean-sea-ice MIT general circulation model (Marshall et al., 1997; Adcroft et al., 2004). The model covers the Atlantic region north of $30^{\circ} \mathrm{S}$ including the Nordic seas and the Arctic Ocean. It has 50 levels in the vertical, with resolution varying from $10 \mathrm{~m}$ in the upper ocean to $550 \mathrm{~m}$ in the deep ocean. It was initialized from rest and with the annual mean temperature and salinity from the World Ocean Atlas (WOA) 2005 monthly climatology
(Boyer et al., 2005). Bottom topography was interpolated from the ETOPO2 database (Smith and Sandwell, 1997).

The model was forced at the surface by fluxes of momentum, heat and freshwater computed using bulk formulae and the 1948-2010 6-hourly atmospheric state from the NCEP RA1 reanalysis (Kalnay et al., 1996). At the southern open boundary the model was forced by a $1^{\circ}$ resolution global model solution, and at Bering Strait a barotropic net inflow of $0.9 \mathrm{~Sv}$ was prescribed. The model sea surface salinity was relaxed to the WOA2005 monthly climatology to prevent longterm drifts. In the area of interest, the Barents and Kara seas including the ST, the horizontal resolution is $7 \mathrm{~km}$.

The vertical mixing parameterization follows the K-profile parameterization (KPP) formulation by Large et al. (1994). Background coefficients of vertical diffusion and viscosity are both $10^{-5} \mathrm{~m}^{2} \mathrm{~s}^{-1}$. Biharmonic diffusion and viscosity represent unresolved eddy mixing, both with coefficients of $5 \times 10^{9} \mathrm{~m}^{4} \mathrm{~s}^{-1}$. Further details on the model setup and an application can be found in Serra et al. (2010).

The model is capable of realistically reproducing the AW inflow into the Arctic Ocean through the Barents Sea Opening (BSO) and Fram Strait. The vertical structure of temperature and velocity at BSO (Fig. 3a) is in overall agreement with that shown in Skagseth (2008). The AW and the Bear Island Trough outflow temperatures (Fig. 3c) are also consistent with observations. Furthermore, the simulated volume transport of AW (defined as $T>3^{\circ} \mathrm{C}$ ) of about $1.7 \mathrm{~Sv}$ (Figs. 1 and $3 \mathrm{e}$ ) agrees well with the $1.8 \mathrm{~Sv}$ value given in Skagseth et al. (2008).

In the Fram Strait, the model performs reasonably well in terms of the vertical structure of mean temperature and velocity (Fig. 3b). The West Spitsbergen Current (WSC) has a realistic structure, and the temperature of the AW (defined as $T>2{ }^{\circ} \mathrm{C}$ - Fig. $3 \mathrm{~d}$ ) is in agreement with the time series presented in Beszczynska-Moeller et al. (2012). The longterm mean (1997-2009) simulated volume transport of AW in the core of the WSC at Fram Strait of about 1.4 Sv is directly comparable with the $1.3 \mathrm{~Sv}$ presented in BeszczynskaMoeller et al. (2012) based on measurements by an array of moorings in Fram Strait over the period 1998-2010 (Figs. 1 and 3f). The maximum mean (2000-2009) temperature in $150-800 \mathrm{~m}$ shows that there is a well-defined inflow of AW, which turns to the right after entering the Fram Strait and gradually loses heat on the way (Fig. 4).

The model's ability to adequately simulate the AW dynamics, and thus to elaborate the relationships between the AW dynamics and ice conditions over the ST region, is briefly discussed elsewhere (Dmitrenko et al., 2012). They also reported on a fair model capability in reproducing the basic hydrography for the downstream area over the Laptev Sea continental margin. 

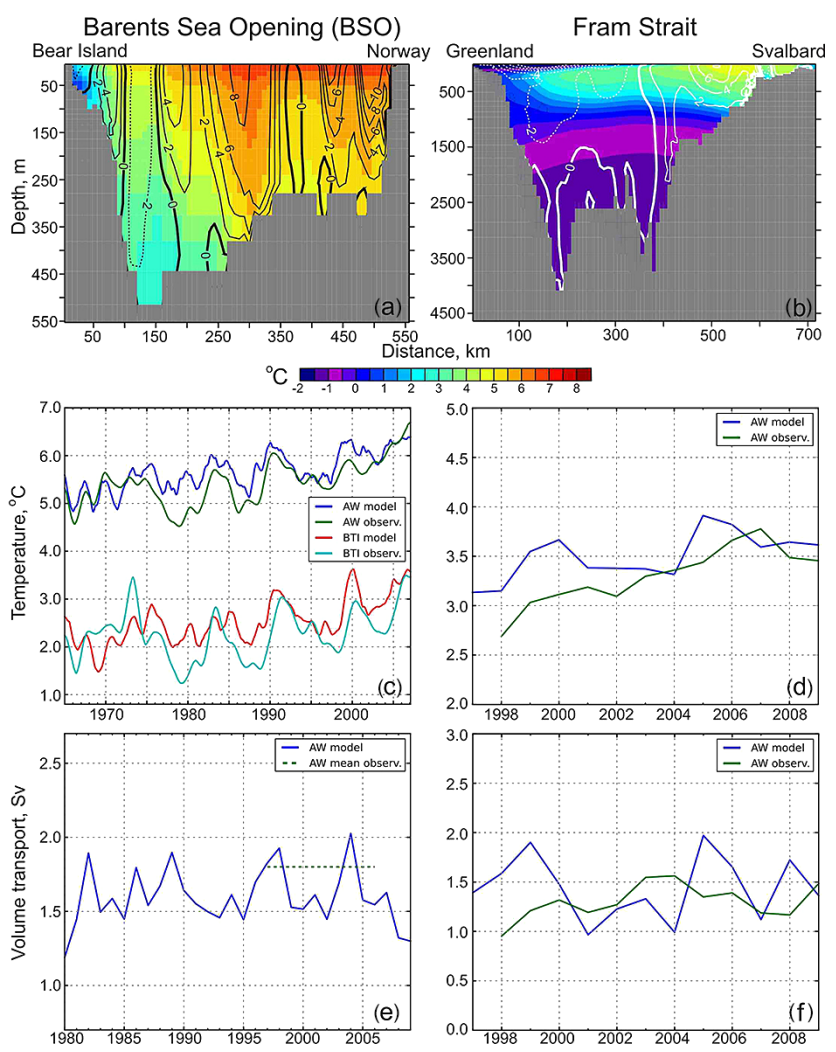

Figure 3. Simulated and observed characteristics of the AW inflow into the Arctic Ocean through the (left) Barents Sea Opening from Bear Island to Norway (BSO) and (right) Fram Strait. The first row shows the simulated mean temperature (in color) and velocity (contour lines) in (a) the Fram Strait from 2002 to 2008, as in Beszczynska-Moeller et al. (2012) and (b) the BSO from 2003 to 2005, as in Skagseth (2008). Positive velocities in (a) and (b) are to the east and north, respectively. (c) Temperature in the AW layer (blue - model, green - observations) defined as the mean between $72-73^{\circ} \mathrm{N}$ and $50-200 \mathrm{~m}$ and in the outflow water in the Bear Island Trough (red - model, cyan - observations) at $73.5^{\circ} \mathrm{N}$, defined as the mean from 300 to $450 \mathrm{~m}$. Definitions and observational data are from Skagseth (2008). (d) The AW mean temperature in the core of the West Spitsbergen Current (WSC) from the model (blue) and observations (green), defined as waters with $T>2{ }^{\circ} \mathrm{C}$ between and $8^{\circ} 40^{\prime}$ E. Definition and observational data are from BeszczynskaMoeller et al. (2012). (e) The AW (defined as $T>3{ }^{\circ} \mathrm{C}$ ) volume transport through the BSO as simulated by the model (blue) with the 1997-2006 mean from observations (green) superimposed (Skagseth et al., 2008). (f) The AW volume transport in the WSC (AW defined as in d), from the model (blue) and observations (green) by Beszczynska-Moeller et al. (2012).

\section{Results}

First, we focus on the patterns of the CTD profiles taken in 2009, which captured the cross-trough temperature maxima in the intermediate water layer conditioned by the AW inflow into the Arctic Ocean. We suggest that these temperature maxima trace the SFSBW pathway in the ST (red arrows in

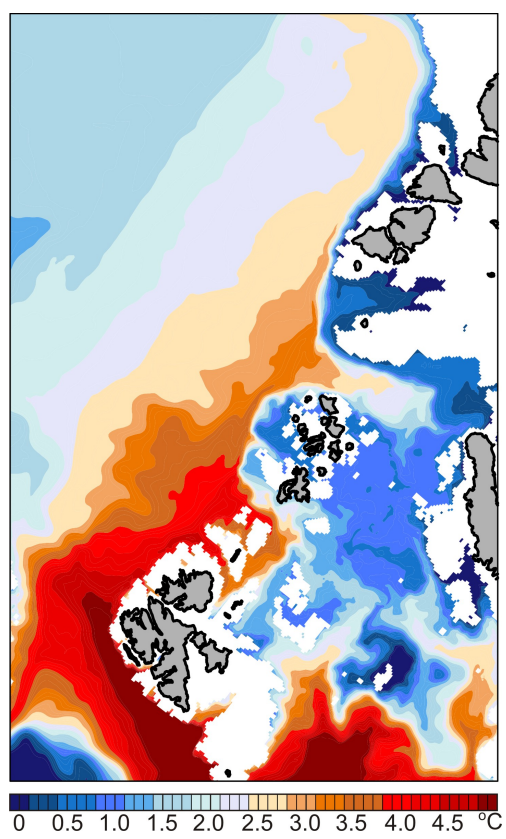

Figure 4. The maximum mean (2000-2009) simulated temperature $\left({ }^{\circ} \mathrm{C}\right)$ in $150-800 \mathrm{~m}$.

Fig. 2). Second, we discuss the density structure across the ST with a main focus on the eastern flank, where the ST outflow is conditioned by the interaction between the Barents Sea outflow and the SFSBW. Third, we focus on the sheared flow along the ST eastern slope, revealed from directly measured, inferred (using geostrophy) and simulated velocities.

The 2009 survey shows the SFSBW core temperatures to decrease continuously along the SFSBW pathway from $2.54^{\circ} \mathrm{C}$ (station 85) to $2.35^{\circ} \mathrm{C}$ (station 23) over the ST western flank, and to $2.20^{\circ} \mathrm{C}$ (station 25) and $2.09^{\circ} \mathrm{C}$ (station 77) over the ST eastern flank (Figs. 2, 5a and b). The same pattern was found by Hanzlick and Aagaard (1980) based on five CTD transects crossing the ST from $\sim 79$ to $82^{\circ} \mathrm{N}$ in 1966 , except that in the 1960s the temperatures were about $1{ }^{\circ} \mathrm{C}$ lower. For the SFSBW inflow, the overlaying water layer from 50 to $\sim 100 \mathrm{~m}$ exhibits well-defined staircases indicating double diffusive upward heat flux from the warm AW layer (Fig. 5a and b). In contrast, the SFSBW outflow shows heavily eroded double diffusive staircases in the upper AW layer. In addition, over the eastern flank of ST, the halocline and the upper SFSBW $(15-80 \mathrm{~m})$ are fresher and less dense relative to the western flank by $\sim 0.3-1.0$ psu (Fig. 5a and b), and $0.3-0.7 \mathrm{~kg} \mathrm{~m}^{-3}$, respectively. At the same time, we observe a deepening of the thermocline and, to a lesser extent, the halocline. All these patterns are in agreement with those revealed by the CTD profiles taken in 1996 (Fig. 5c) and 2008 (not shown; note that no hydrographic information for the western ST is available for 2010). The 1996 CTD profiles taken in July show a relatively cool and saline surface layer with lower/higher salinity/temperature vertical 


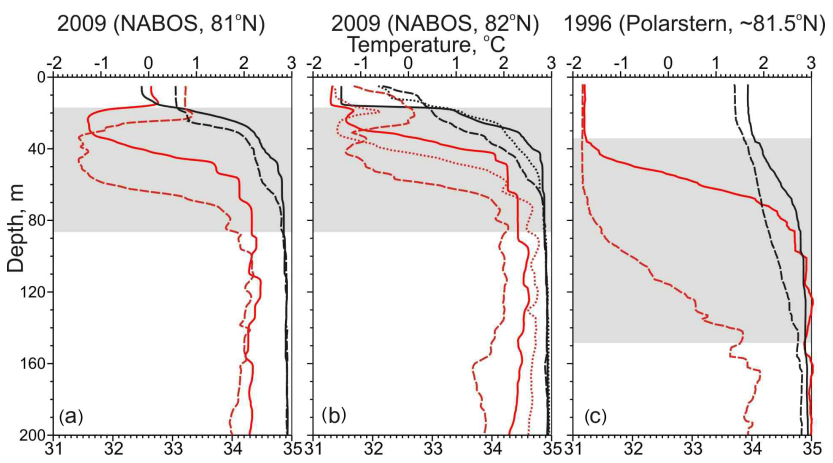

Figure 5. Vertical profiles of temperature (red, ${ }^{\circ} \mathrm{C}$ ) and salinity (black, psu) in the upper $200 \mathrm{~m}$ layer taken in July 1996 and September 2009 through the core of SFSBW inflow (solid line, $\mathbf{a}$ - station $23, \mathbf{b}$ - station $85, \mathbf{c}-81^{\circ} 27^{\prime} \mathrm{N}, 65^{\circ} 51^{\prime} \mathrm{E}$ ) and outflow (dashed line, $\mathbf{a}$ - station $25, \mathbf{b}$ - station $77, \mathbf{c}-81^{\circ} 17^{\prime} \mathrm{N}, 72^{\circ} 01^{\prime} \mathrm{E}$ ) to/from the ST. (b) The dotted line depicts the CTD profile taken in September 2009 through the core of the FSBW boundary current (station 80). For station positions in 2009 see Fig. 2. Gray shading highlights the outflow from the ST modified by vertical mixing.

gradients comparing to the 2009 profiles taken in late August to early September (Fig. 5). This difference implies the role of seasonal variability attributed to the sea ice melting and solar heating. The higher temperature of the inflowing SFSBW in 1996 compared to 2008 is due to the warm AW anomaly entering the Arctic Ocean through the Fram Strait in the 1990s (e.g., Schauer et al., 2002b). We also note that in 2009 the intermediate temperature maximum $\left(T_{\max }=2.74^{\circ} \mathrm{C}\right)$ in the central part of the ST mouth at $82^{\circ} \mathrm{N}$ (station 80, Figs. 2 and $5 b$ ) exceeds that of the inflowing SFSBW by $0.2-0.4^{\circ} \mathrm{C}$.

The observations in 1996 and 2008-2010 consistently show denser water at the eastern flank of the ST below the halocline layer deeper than $50 \mathrm{~m}$ (Fig. 6). In 1996, over the ST eastern flank shallower than $\sim 300 \mathrm{~m}$, the density front extended throughout the water column (Fig. 6a). At $150 \mathrm{~m}$, the potential density gradient across the eastern flank along $81^{\circ} \mathrm{N}$ ranged from $0.09 \times 10^{-2} \mathrm{~kg} \mathrm{~m}^{-3} \mathrm{~km}^{-1}$ in 2010 (Fig. 6d) to $0.18 \times 10^{-2} \mathrm{~kg} \mathrm{~m}^{-3} \mathrm{~km}^{-1}$ in 2008-2009 (Fig. 6b and c). At $300 \mathrm{~m}$, the cross-slope density gradient in 2008-2010 was more uniform with $\sim 0.16-0.18 \times$ $10^{-2} \mathrm{~kg} \mathrm{~m}^{-3} \mathrm{~km}^{-1}$ (Fig. 6b-d). For comparison, in 1996, the density gradient across the eastern flank was $\sim 0.22 \times 10^{-2}$ and $0.09 \times 10^{-2} \mathrm{~kg} \mathrm{~m}^{-3} \mathrm{~km}^{-1}$, at 150 and $300 \mathrm{~m}$, respectively (Fig. 6a). Moreover, in 1996 the surface layer is denser (saltier), and consequently the surface layer stratification is weaker (Fig. 5a).

The mean velocity profile derived from the 2009-2010 year-long ADCP velocity measurements at the eastern flank shows a relatively stable, nearly barotropic northward flow aligned to $\sim 2^{\circ}$ in $140-220 \mathrm{~m}$ and to $\sim 11^{\circ}$ in $380-460 \mathrm{~m}$, which is consistent with the orientation of the ST eastern flank. The flow strength slightly increases with depth from $17 \pm 7 \mathrm{~cm} \mathrm{~s}^{-1}$ at $140 \mathrm{~m}$ to $18 \pm 7 \mathrm{~cm} \mathrm{~s}^{-1}$ at $200 \mathrm{~m}$ (Fig. 6b),

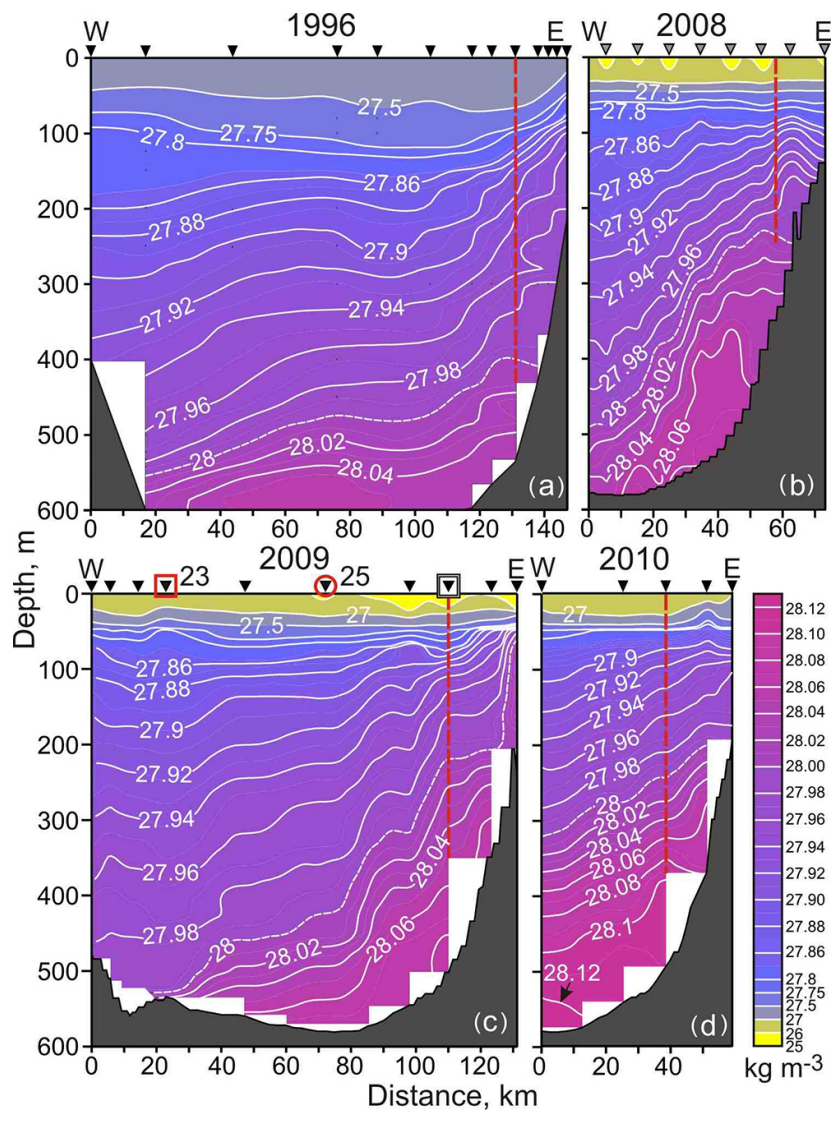

Figure 6. The $10 \mathrm{~m}$ binned cross-trough sections of potential density ( $\sigma$-zero, $\mathrm{kg} \mathrm{m}^{-3}$ ) along $81^{\circ} \mathrm{N}$ for (a) July 1996, (b) September 2008, (c) September 2009 and (d) October 2010. Black and gray triangles on the top identify positions of CTD and XCTD stations, respectively. Following Fig. 2, the red square and circle and the white square identify stations taken through the core of the SFSBW inflow and outflow to/from the ST and mooring position, respectively, with their reference numbers on the top. Red dashed lines identify locations of the geostrophic velocity profiles shown in Fig. 7a. The white dashed line highlights the $\sigma$-zero $=28 \mathrm{~kg} \mathrm{~m}^{-3}$, which roughly corresponds to the core of the cooler fraction of BSBW (Dmitrenko et al., 2008a, 2009).

$21 \pm 5 \mathrm{~cm} \mathrm{~s}^{-1}$ at $380 \mathrm{~m}$, and $23 \pm 5 \mathrm{~cm} \mathrm{~s}^{-1}$ at $460 \mathrm{~m}$ (not shown). This is in agreement with the ship-board ADCP observations in 1996 showing the northward sub-surface flow of $\sim 25-30 \mathrm{~cm} \mathrm{~s}^{-1}$ (Fig. 7b, see Schauer et al., 2002a, for more details). In addition, the velocity profile in Fig. $7 \mathrm{~b}$ demonstrates a velocity difference of $\sim 20 \mathrm{~cm} \mathrm{~s}^{-1}$ in the upper $90 \mathrm{~m}$. The sheared flow is also evident from the geostrophic velocity profiles at the mooring position in the ST eastern flank derived from dynamic heights relative to the 0 dbar pressure surface using the potential density profiles from the nearest CTD stations (Figs. 6 and 7a). The simulated velocities also demonstrate a northward sheared flow along the ST eastern flank, but twice as large as the geostrophic velocities (Figs. 7c, d, and 8). 


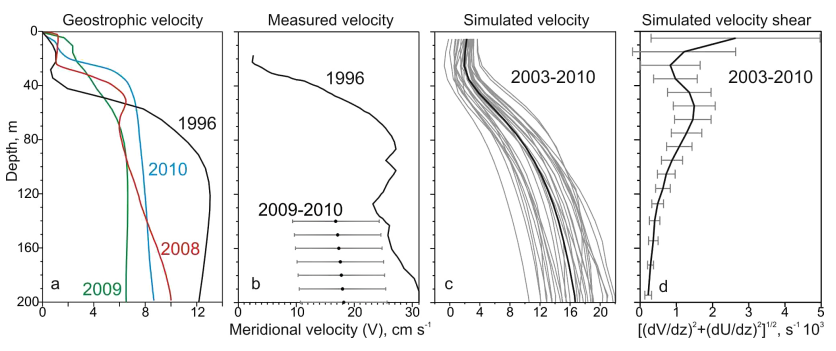

Figure 7. Vertical velocity profiles for the northward current over the ST eastern flank: (a) geostrophic, (b) measured and (c) simulated for each grid node over the ST eastern flank between 78 and $81^{\circ} \mathrm{N}$ (gray lines, averaged for 2003-2010 using annual mean velocity profiles) with their mean (black line). (d) Vertical profile of the simulated velocity shear at the mooring position averaged for 2003-2010 using daily mean velocity profiles. (b, d) Error bars show 1 standard deviation from the mean.

\section{Discussion}

\subsection{Heat loss from the AW in the ST: causes}

Expanding on the AW circulation scheme suggested by Rudels et al. (1994) (Fig. 1), we have demonstrated that a significant portion of the heat associated with the SFSBW in the ST disappears en route through the ST. In this context, our observations confirm earlier findings by Hanzlick and Aagaard (1980). This concept, however, requires explanation for the AW intermediate temperature maximum of $2.74{ }^{\circ} \mathrm{C}$ observed in the ST mouth at $82^{\circ} \mathrm{N}$ (station 80) that exceeds the temperature of the SFSBW inflow and outflow by 0.2 and $0.65^{\circ} \mathrm{C}$, respectively (Fig. 5a and b).

The current view on the AW circulation in the Eurasian Basin, as proposed by Rudels et al. (2004), implies that the FSBW could potentially feed all three temperature maxima along $82^{\circ} \mathrm{N}$ recorded at stations 77,80 , and 85 (Fig. 2). However, the formation of each maximum is due to different FSBW branches. That is, if the ST on-slope temperature maxima are associated with SFSBW, then the AW temperature maximum in the ST mouth could be attributed to the boundary current of the FSBW flowing along the Siberian continental slope (yellow arrows in Fig. 2). The double diffusive staircases noticeable in station 80 (Fig. 5b) provide indication of attributing the intermediate temperature maximum of $2.74{ }^{\circ} \mathrm{C}$ to the core of the FSBW that follows the Siberian continental slope rather than to the SFSBW. In contrast to the SFSBW inflow (stations 23 and 85), the CTD profiles taken in the SFSBW outflow (stations 25 and 77) show heavily eroded double diffusive staircases (Fig. 5a and b). The ST outflow also exhibits strong modification at the upper AW interface, which is likely caused by vertical mixing and interaction with cooler and fresher surface water of Barents Sea origin. In contrast, the temperature and salinity profiles in the ST mouth (station 80) are only slightly modified at the upper AW interface and maintain double diffusive staircases

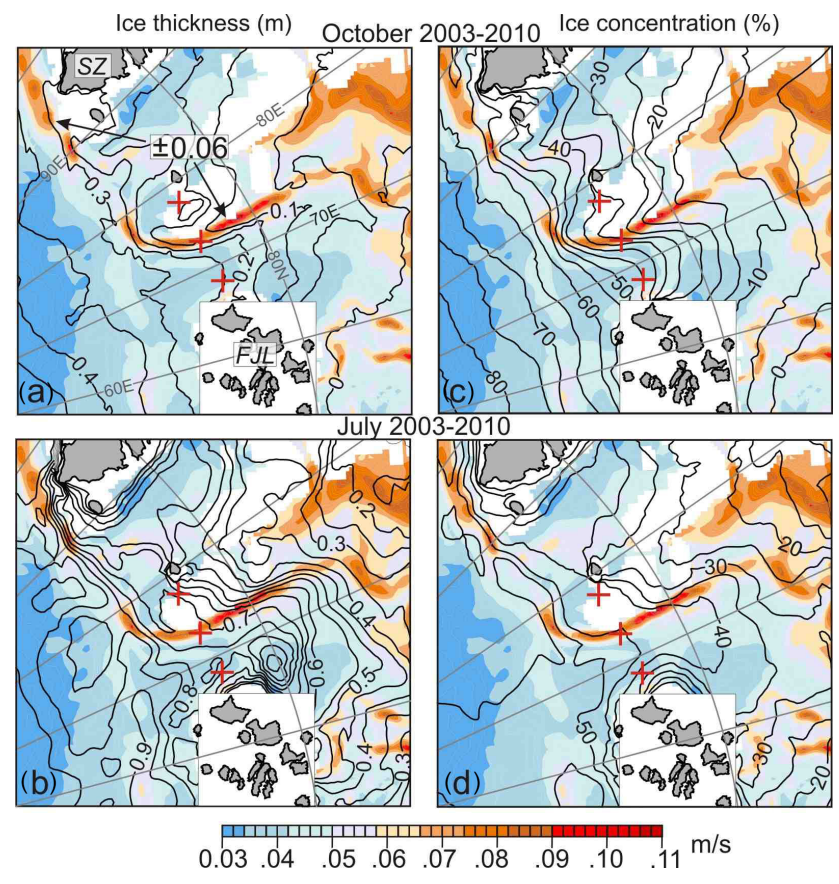

Figure 8. The 7-year mean (2003-2010) simulated velocity vertical difference $(\Delta V)$ in the $0-75 \mathrm{~m}$ layer $\left(\mathrm{m} \mathrm{s}^{-1}\right)$ in the northern Kara Sea with overlaid simulated mean $(\mathbf{a}, \mathbf{b})$ sea-ice thickness $(\mathrm{m})$ and $(\mathbf{c}, \mathbf{d})$ concentration $(\%)$ for $(\mathbf{a}, \mathbf{c})$ October and (b, d) July. Crosses depict locations along $81^{\circ} \mathrm{N}$ where the measured June-November time series of sea-ice concentration are compiled in Fig. 12. (a) The arrowed number shows \pm 1 standard deviation for the $\Delta V$ maximum over the ST eastern flank and Kara Sea continental margin obtained using monthly mean velocity data.

that are almost disrupted in stations 25 and 77 (Fig. 5a and b).

The enhanced turbulent diffusivity usually results in substantial degradation of the thermohaline staircases, and the turbulent mixing associated with shear instability nearly disrupts the double-diffusive staircases (e.g., Melling et al., 1984; Dmitrenko et al., 2008a). Over the ST eastern flank, turbulent mixing between the upper SFSBW and overlaying cooler and fresher Barents and Kara Sea waters may be inferred from the velocity shear across the upper SFSBW interface (Figs. 7 and 8). The cross-trough potential density distribution in Fig. 6 is also consistent with a sheared geostrophic flow above the eastern ST (Fig. 7a). Under this scenario, the SFSBW inflow (double-diffusive staircases present) has not been affected by enhanced turbulent mixing, while the SFSBW outflow (no double-diffusive staircases present) has experienced turbulent mixing during propagation along the eastern ST. The FSBW boundary current at the central ST (station 80 ) has been partly affected by turbulent mixing, but double-diffusive staircases remain recognizable.

The sheared flow along the eastern ST in the upper $100 \mathrm{~m}$ layer is evident from direct current observations (Fig. 7b), geostrophic velocity calculations (Fig. 7a), and 
model simulations (Figs. 7c, d and 8). However, the difference between measured and geostrophic velocities indicates that the SFSBW flow along the eastern ST is not entirely density driven. In this context, Kirillov et al. (2012) recently showed that wind forcing over the northern Kara Sea is important in facilitating the SFSBW outflow from the ST. The gradient Richardson number $(R i)$ provides a strong constraint for identifying turbulence produced by shear instability. It is defined as $R i=N^{2} S^{-2}$, where $N$ is the Brunt-Väisälä frequency, and $S$ is the flow vertical shear $S=\left[(\mathrm{d} U / \mathrm{d} z)^{2}+\right.$ $\left.(\mathrm{d} V / \mathrm{d} z)^{2}\right]^{1 / 2}$. Turbulent mixing can be assumed to occur for $R i<1$ (e.g., Polzin, 1996). Considering a velocity shear $S \sim 0.004 \mathrm{~s}^{-1}$ and the stratification in the 30-90 m layer observed in 1996 (Figs. 6d and 7b) results in $R i=3.7$, which significantly exceeds the criterion. Simulations show, however, that velocity shear across the surface layer might reach $0.007 \mathrm{~s}^{-1}$ (Fig. 7d). Assuming the higher $S \sim 0.007 \mathrm{~s}^{-1}$ induced by the SFSBW northward velocity $V \sim 40 \mathrm{~cm} \mathrm{~s}^{-1}$, as measured in January 2010 (not shown), the $O(R i)=1.4$ might possibly allow for turbulent mixing, taking into account reduced salinity (density) stratification in winter due to sea-ice formation. While it cannot be shown explicitly that shear instability is entirely responsible for the enhanced vertical mixing, it may play a role in facilitating upward fluxes from the AW over the ST eastern slope.

An important amount of the AW heat loss in the ST may be attributed to strong vertical mixing over the ST flanks and associated rough topography. Sundfjord et al. (2007) and Sirevaag and Fer (2009) concluded that the Arctic turbulent mixing is important along the boundaries and steep bottom topography. The enhanced vertical diffusion can be also associated with elevated tidal forcing over the sloping topography (e.g., Dewey at al., 1999). In the following, however, we show that the enhanced vertical heat loss occurs specifically over the ST eastern flank, the area where the SFSBW flows to the Arctic Ocean.

\subsection{Heat loss from the AW in the ST: estimates}

In 2009, the heat content of the SFSBW inflow over the western ST flank computed relative to the freezing temperature between 30 to $90 \mathrm{~m}$ depth decreased by $\sim 340 \mathrm{MJ} \mathrm{m}^{-2}$ upon reaching the eastern flank. For example, at $81^{\circ} \mathrm{N}$ the heat content between 30 to $90 \mathrm{~m}$ depth decreased from $796 \mathrm{MJ} \mathrm{m}^{-2}$ at station 23 (SFSBW inflow) to $457 \mathrm{MJ} \mathrm{m}^{-2}$ at station 25 (SFSBW outflow). We note, however, the opposite tendency of the heat content over the eastern ST between stations 25 and 77, showing increase from $457 \mathrm{MJ} \mathrm{m}^{-2}$ at station 25 to $584 \mathrm{MJ} \mathrm{m}^{-2}$ at station 77 (Fig. 2). This discrepancy seems to be attributed to a crude spatial resolution of our time snapshot CTD data, which are insufficient to resolve the relatively narrow jet of the AW outflow from the ST. At $81^{\circ} \mathrm{N}$, the horizontal cross-slope temperature gradient between stations 26 and 27 at $110 \mathrm{~m}$ (depth of the temperature maximum at station 25 - Fig. 3a) is $0.18^{\circ} \mathrm{C} \mathrm{km}^{-1}$, and the horizontal cross-slope gradient of heat content is $16.25 \mathrm{MJ} \mathrm{m}^{-2} \mathrm{~km}^{-1}$ (Fig. 2). We hypothetically extend this gradient further offslope to station 26 in order to obtain an estimate of uncertainty related to spatial undersampling of the relatively narrow AW jet between stations 25 and 26. This approach gives heat content estimates from $457 \mathrm{MJ} \mathrm{m}^{-2}$ to $629.75 \mathrm{MJ} \mathrm{m}^{-2}$ in $\sim 4 \mathrm{~km}$ to $15 \mathrm{~km}$ off station 26 , respectively (note that the distance between station 25 and 26 is $\sim 16 \mathrm{~km}$ ). This suggests the upper bound of potential heat content underestimate at station 26 to be $173 \mathrm{MJ} \mathrm{m}^{-2}$.

In the following we assume that all heat loss in the SFSBW occurs along the ST eastern flank downstream of the SFSBW confluence with the Barents Sea water outflow to the ST at $\sim 78^{\circ} \mathrm{N}$. This assumption is based on the hypothesis that the SFSBW heat loss is primarily driven by the velocity shear over the ST eastern flank, in line with model simulations showing no velocity shear over the ST western flank (Fig. 8). This suggestion also implies neglecting the double diffusive heat loss from the AW over the ST western flank, which is justified by the typical double diffusive heat flux estimated in the Arctic Ocean to $0.6 \mathrm{~W} \mathrm{~m}^{-2}$ (Sirevaag and Fer, 2012). Moreover, this assumption is also based on the structure of the temperature profiles, showing that the major part of the deepening of the upper SFSBW interface occurs from $81^{\circ} \mathrm{N}$ on the western flank to $81^{\circ} \mathrm{N}$ on the eastern flank (Fig. 5). Furthermore, we neglect the lateral heat loss, particularly by a fraction of the SFSBW flowing west along the shallower trough between Novaya Zemlya and Franz Josef Land - Fig. 1 (e.g., Schauer et al., 2002a; Gammelsrød et al., 2009).

The travel time along the eastern ST flank between $78^{\circ} \mathrm{N}$ and the mooring location at $81^{\circ} \mathrm{N}$ is estimated using northward along-trough velocities simulated with the MIT model. At each grid node over the eastern flank, the simulated velocity profiles were averaged from 2003 to 2010 (Fig. 7c). The mean velocity profile computed from averaging all individual profiles over the eastern ST shows $\sim 10 \mathrm{~cm} \mathrm{~s}^{-1}$ northward velocity for the SFSBW core at $\sim 90 \mathrm{~m}$ (Fig. 7c). This velocity implies a $\sim 40$-day travel time from 78 to $81^{\circ} \mathrm{N}$ along the ST eastern flank, the area where the heat content of the SFSBW was suggested to reduce by $\sim 340 \mathrm{MJ} \mathrm{m}^{-2}$. This is equivalent to an upward vertical heat flux from the SFSBW to the low halocline water of $\sim 100 \mathrm{~W} \mathrm{~m}^{-2}$. This rough estimate is similar to those reported by Sirevaag and Fer (2009) for the area north of Svalbard where the upward heat loss from the AW is among the largest throughout the Arctic Ocean (e.g., Steele and Morison, 1993). For comparison, over the Laptev Sea continental margins, Polyakov et al. (2012) estimated the heat flux across the upper AW interface of $\sim 8 \mathrm{~W} \mathrm{~m}^{-2}$. Microstructure measurements over the Laptev Sea continental shelf break reveal upward heat fluxes of $12 \mathrm{~W} \mathrm{~m}^{-2}$ (Lenn et al., 2011). An estimate of the uncertainty in the vertical heat flux owing to spatial undersampling of the AW jet at $81^{\circ} \mathrm{N}$ is obtained based on the heat content underestimate 


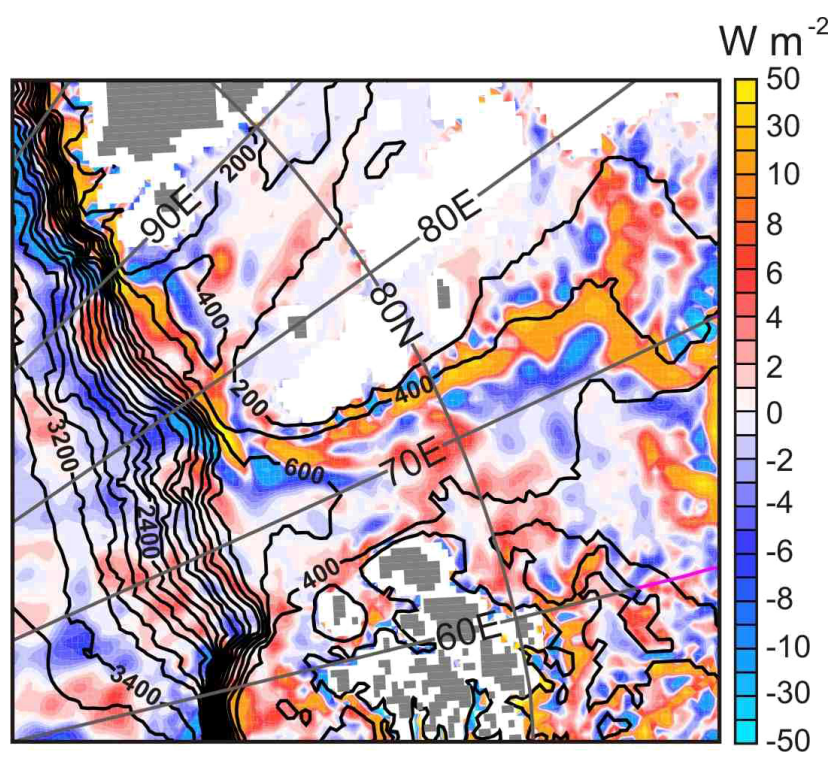

Figure 9. The 7-year mean (2003-2010) simulated vertical heat fluxes $\left(\mathrm{W} \mathrm{m}^{-2}\right)$ across the upper SFSBW interface at $75 \mathrm{~m}$ showing enhanced heat loss over the ST eastern flank as well as over the Nansen Basin continental margin. Positive numbers indicate upward heat flux. The bathymetry is in meters. Yellow dashed rectangular depicts the area over the ST eastern flank where the simulated heat flux is averaged for compiling the time series shown in Fig. 10.

by $173 \mathrm{MJ} \mathrm{m}^{-2}$, which reveals the heat flux lower bound of $\sim 50 \mathrm{~W} \mathrm{~m}^{-2}$.

Over the ST eastern flank, our model simulations show a mean upward heat flux across the upper SFSBW interface with values up to $30-50 \mathrm{~W} \mathrm{~m}^{-2}$ (Fig. 9) that is about half or less the heat loss compared with estimates inferred from CTD observations in the ST. The areal mean over the ST eastern flank is $21 \pm 18 \mathrm{~W} \mathrm{~m}^{-2}$. The difference between simulated and CTD-derived values indicates that the double diffusive heat loss over the ST western flank and the lateral heat loss might be also important. On the other hand, the model presents a large spatial and temporal variability in the vertical heat fluxes at the upper SFSBW interface, with values at times exceeding $80 \mathrm{~W} \mathrm{~m}^{-2}$ (Fig. 10). The daily averaged values of the upward heat flux in the model ST eastern flank (Fig. 10) present a seasonal cycle of about $20 \mathrm{~W} \mathrm{~m}^{-2}$, showing a main maximum in early spring and a secondary maximum in early winter. Furthermore, strong interannual variability on the occurrence of the spring maximum can be noticed.

In view of such strong variability, the inconsistency to the observations might be, in part, attributed to unresolved temporal variability in the measurements. An incomplete mixing scheme in the model might also provide an explanation for model-observational discrepancies. Finally, the discrepancy between estimates derived from simulations and CTD data can also be explained by spatial undersampling of the AW jet over the ST eastern slope. The lower bound of heat flux at

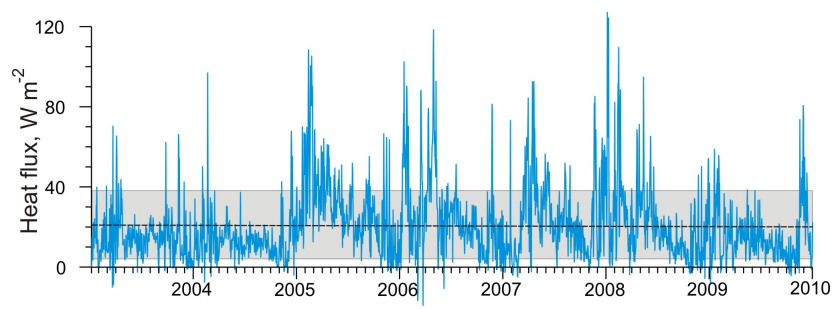

Figure 10. Time series (2003-2010) of daily mean simulated vertical heat fluxes $\left(\mathrm{W} \mathrm{m}^{-2}\right)$ across the upper SFSBW interface at $75 \mathrm{~m}$ averaged over the ST eastern slope (the area depicted by the yellow dashed rectangle in Fig. 9). The black dashed line indicates the 2003-2010 mean (20.5 $\left.\mathrm{W} \mathrm{m}^{-2}\right)$ and the gray shading shows \pm 1 standard deviation from the mean.

$\sim 50 \mathrm{~W} \mathrm{~m}^{-2}$ retrieved from the CTD data is consistent with the 7-year mean simulated vertical heat fluxes (Fig. 9).

In summary, both the CTD data and the model simulation suggest the upward heat loss from the AW layer in the ST eastern flank, significantly exceeding that over the Siberian continental margin. The spatial undersampling results in relatively high uncertainty of our observationally based heat loss estimates. However, even at the lower bound of $\sim 50 \mathrm{~W} \mathrm{~m}^{-2}$ the amount of heat transferred to the upper layer is capable of modifying the sea ice cover, as we discuss in the following section.

\subsection{Heat loss from the AW in the ST: impact on sea ice}

In what follows we test our hypothesis of enhanced SFSBW heat loss in the ST by using sea-ice remote sensing data. The fraction of the AW heat expended for heating the overlaying water depends on the characteristics of the Barents Sea outflow. However, any upward heat flux reaching the sea surface will eventually affect the ocean-sea-ice-atmosphere interface (e.g., through reduced sea-ice thickness, enthalpy flux to the atmosphere and delayed freeze-up). The winter mean (February-March) sea-ice thickness derived from five ICESat winter campaigns in 2004-2008 (Kwok et al., 2009) shows an area with negative anomalies of $\sim 20 \mathrm{~cm}$ stretching from the ST mouth towards Severnaya Zemlya following the Nansen Basin continental margin (Fig. 11a; note that there is no available ICESat data south of $81^{\circ} \mathrm{N}$ ). This is consistent with the simulated velocity difference in Fig. 8 and enhanced upward heat loss along the SFSBW pathway (Fig. 9). In February-March 2004-2008, the ice drift over the ST mouth is mainly westward with a mean velocity of $\sim 4 \mathrm{~km} \mathrm{day}^{-1}$ (Fig. 10b and c). The mean width of the ST eastern slope at the ST mouth is $\sim 50 \mathrm{~km}$. This yields a $\sim 12.5$-day pack ice residence time over the $\mathrm{ST}$ eastern slope at $82.5^{\circ} \mathrm{N}$, where pack ice is exposed to the enhanced upward vertical heat flux from the SFSBW. The $20 \mathrm{~cm}$ sea-ice decrease in 12.5 days requires an upward heat flux of $\sim 60 \mathrm{~W} \mathrm{~m}^{-2}$ to the icewater interface, which is comparable to that obtained from the model simulations (Fig. 9). 


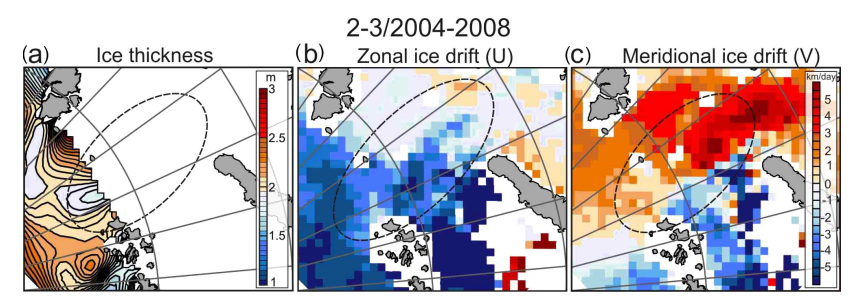

Figure 11. The 2004-2008 winter mean (February-March) (a) sea ice thickness (m) and (b) zonal and (c) meridional sea ice drift $\left(\mathrm{km} \mathrm{day}^{-1}\right)$ derived from AMSR data. The dashed oval highlights the ST region.

The time series of ice concentration across ST at $81^{\circ} \mathrm{N}$ reveals later freeze-up and earlier sea-ice decline at the eastern flank $\left(73^{\circ} \mathrm{E}\right.$; mooring position), lagging the more western and eastern locations at 68 and $78^{\circ} \mathrm{E}$, respectively, by $\sim 0.5-2.5$ months (Fig. 12). This is in agreement with simulated sea-ice concentrations showing consistent reduction over the ST eastern flank during freeze-up (October, contours in Fig. 8c) and melting (June, contours in Fig. 8d). For estimating the sea-ice growth during freeze-up, we use the semi-empirical method based on an analytical model known as the classical Stefan law (Stefan, 1891) that links the thermodynamic sea-ice growth to the cumulative surface air temperature below freezing. The accumulated seaice growth time series for 2005-2011 computed based on the surface air temperature from the NCEP reanalysis are shown in Fig. 13. For simplicity, we focus on satellite overpass times where the estimated thermodynamic sea-ice growth reaches $\sim 20 \mathrm{~cm}$, which roughly corresponds to the fall and winter sea-ice thickness anomaly over ST in Figs. 8a and 10a, respectively. In contrast to the expected thermodynamic seaice growth of $\sim 20 \mathrm{~cm}$, the ST eastern flank remains ice free even during the late fall at air temperatures far below freezing $\left(\sim-15^{\circ} \mathrm{C}\right)$. For instance, on 25 October 2005 (Fig. 14a) the NCEP-derived daily mean air temperature was as low as $-14^{\circ} \mathrm{C}$, which corresponds to a thermodynamic sea-ice growth of $\sim 2 \mathrm{~cm} \mathrm{day}^{-1}$ (Fig. 13). Melting this amount of ice requires $\sim 70 \mathrm{~W} \mathrm{~m}^{-2}$, a value approaching the upward heat flux inferred from the model simulation (Figs. 9 and 10). We note that this method overestimates the heat loss because Stefan's law does not account for solar insolation.

The observed ice-free area, stretching along the ST eastern flank (Fig. 14), is fully consistent with our assumption of a substantial AW heat loss along the eastern flank corroborated by the model simulation. Figure 14 is also in agreement with simulated sea ice thickness and concentration showing significant reduction over the ST eastern flank in October (Fig. 8a and c). Another remarkable feature of sea ice in the ST is that in 2005, 2007, 2008, 2009 and 2011 the area of reduced sea-ice concentration (45-85\%) was stretched along the ST eastern flank further north to the ST mouth at $\sim 82^{\circ} \mathrm{N}$ where it turned east following the Nansen Basin continental

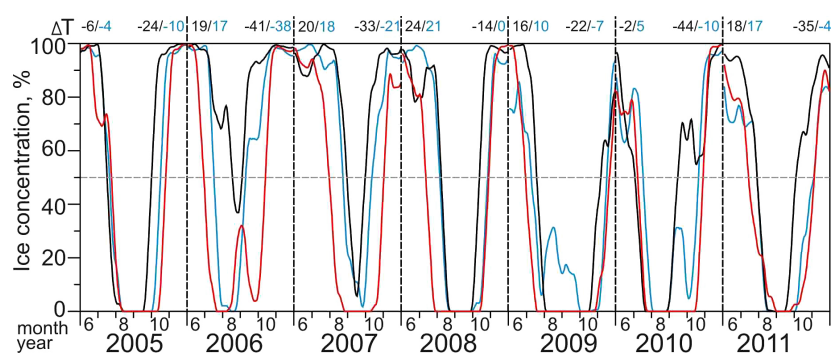

Figure 12. Observed June-November time series of sea ice concentration (\%) at three locations along $81^{\circ} \mathrm{N}$ depicted with crosses in Figs. 8 and $12 \mathrm{a}: 68^{\circ} \mathrm{E}$ (black), $73^{\circ} \mathrm{E}$ - mooring position (red), and $78^{\circ} \mathrm{E}$ (blue). Black/blue numbers at the top show the time lag ( $\Delta T$, days) between $73^{\circ} \mathrm{E}$ and $68 / 78^{\circ} \mathrm{E}$ on reaching the $50 \%$ sea ice concentration.

slope (e.g., Fig. 14c). This is also in line with (i) the spatial distribution of sea ice thickness anomaly in Fig. 11a and (ii) the enhanced AW heat loss simulated along the Kara Sea continental slope (Fig. 9).

The BSBW, entering the Arctic Ocean along the ST, can also potentially impact the sea ice in this region (compare the BSBW pathway and configuration of the open water area in the ST - Figs. 1 and 13). At the Barents Sea exit between Novaya Zemlya and Franz Josef Land, Årthun and Schrum (2010) simulated a long-term mean surface heat flux from the ocean of $\sim 10 \mathrm{~W} \mathrm{~m}^{-2}$, which modified the ice cover distribution as shown in Arthun et al. (2012). However, en route to the ST, the warm core of the BSBW with temperatures above $0^{\circ}$ and salinities between 34.8 and 35 psu is decoupled from the sea surface occupying the depths deeper than 70-100 m (Gammelsrød et al., 2009; Lien and Trofimov, 2013). Within the ST, the warm BSBW core submerges even below the SFSBW (e.g., Dmitrenko et al., 2008a, 2009). This suggests that the BSBW does not play a role in modifying the sea-ice conditions over the ST through direct heat loss.

\section{Summary and concluding remarks}

We have shown that the St. Anna Trough is one area of the Arctic Ocean where AW heat loss can modify the ocean-seaice-atmosphere interface affecting both the formation and decay of sea ice. In this sense, the St. Anna Trough is similar to an "ice bay" known as Whalers' Bay formed by inflowing Fram Strait branch of AW north of Svalbard (e.g., Rudels, 2010; Ivanov et al., 2012). The sheared St. Anna Trough outflow to the Arctic Ocean is evident from shipboard ADCP as well as from geostrophic velocities and a numerical model simulation. Although no clear evidence for the occurrence of shear instabilities could be obtained, we speculate that the enhanced upward heat flux in the St. Anna Trough is promoted by a vertical velocity shear along the St. Anna Trough eastern flank. We show that the zone of lowered sea ice thickness and concentration essentially marks the Fram Strait branch 


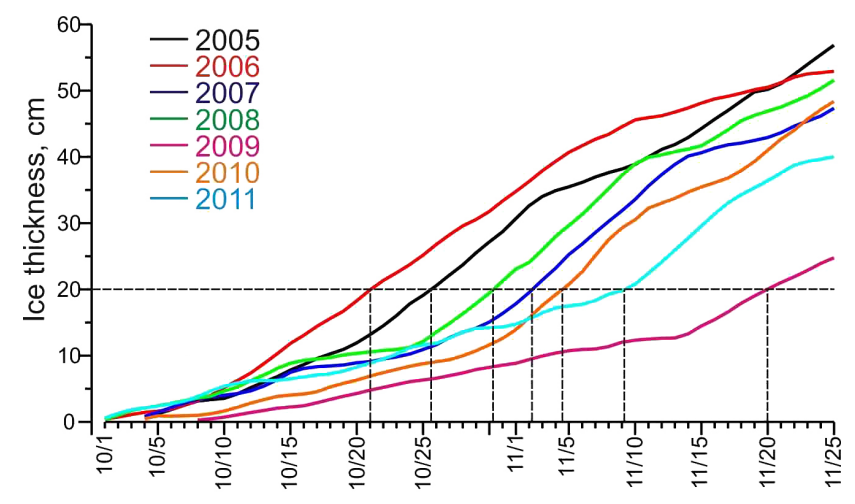

Figure 13. Time series of accumulated thermodynamic sea ice growth (cm) computed for October-November 2005-2011. Dashed lines indicate days in October-November when sea ice thickness reached $20 \mathrm{~cm}$.

pathway in the St. Anna Trough and adjacent Nansen Basin continental margin from both sea-ice remote sensing observations and a model simulation.

Our analysis was significantly limited by the availability of velocity data, and our heat flux estimates based on CTD observations were necessarily illustrative. Our cross-trough CTD transects are time snapshots, and the crude spatial resolution is insufficient to resolve the jet of the AW outflow from the St. Anna Trough. We also note that our estimates of the heat flux at the ice-water interface using sea-ice remote sensing show a lower bound because water and sea-ice dynamics are not taken into account. Moreover, we note that heat loss from the St. Anna Trough recirculating Fram Strait branch is not entirely available for sea-ice melt, and its important fraction is likely to be consumed for modifying the overlaying water and atmospheric boundary layer. The lateral and downward heat loss were not considered and estimated. We also note that although Stefan's law is a simplification of the requisite physics it does provide first-order agreement in our observed surface temperature fluxes and the thermodynamic response of the sea ice.

Finally, our CTD observations cover a relatively short period of time, while over the last several decades the temperature of the FSBW has shown sustainable tendency to rise with several significant warm pulses in the 1990s (e.g., Schauer et al., 2002b) and 2000s (e.g., Dmitrenko et al., 2008b). In fact, our conclusions are based on measurements taken in 1996 and 2008-2010 during the warm pulses of the AW inflow into the Arctic Ocean through the Fram Strait. These conditions represent relatively well the modern tendency of FSBW temperature to rise. At the same time, the physical mechanisms of the upward heat loss in the ST are not obvious, in the light of the ongoing warming with a possible increased ocean heat transport from the Atlantic into the Arctic Ocean (e.g., Koenigk and Brodeau, 2013). It seems that they depend not only on the AW temperature in the SFSBW but also on the vertical velocity shear controlled by

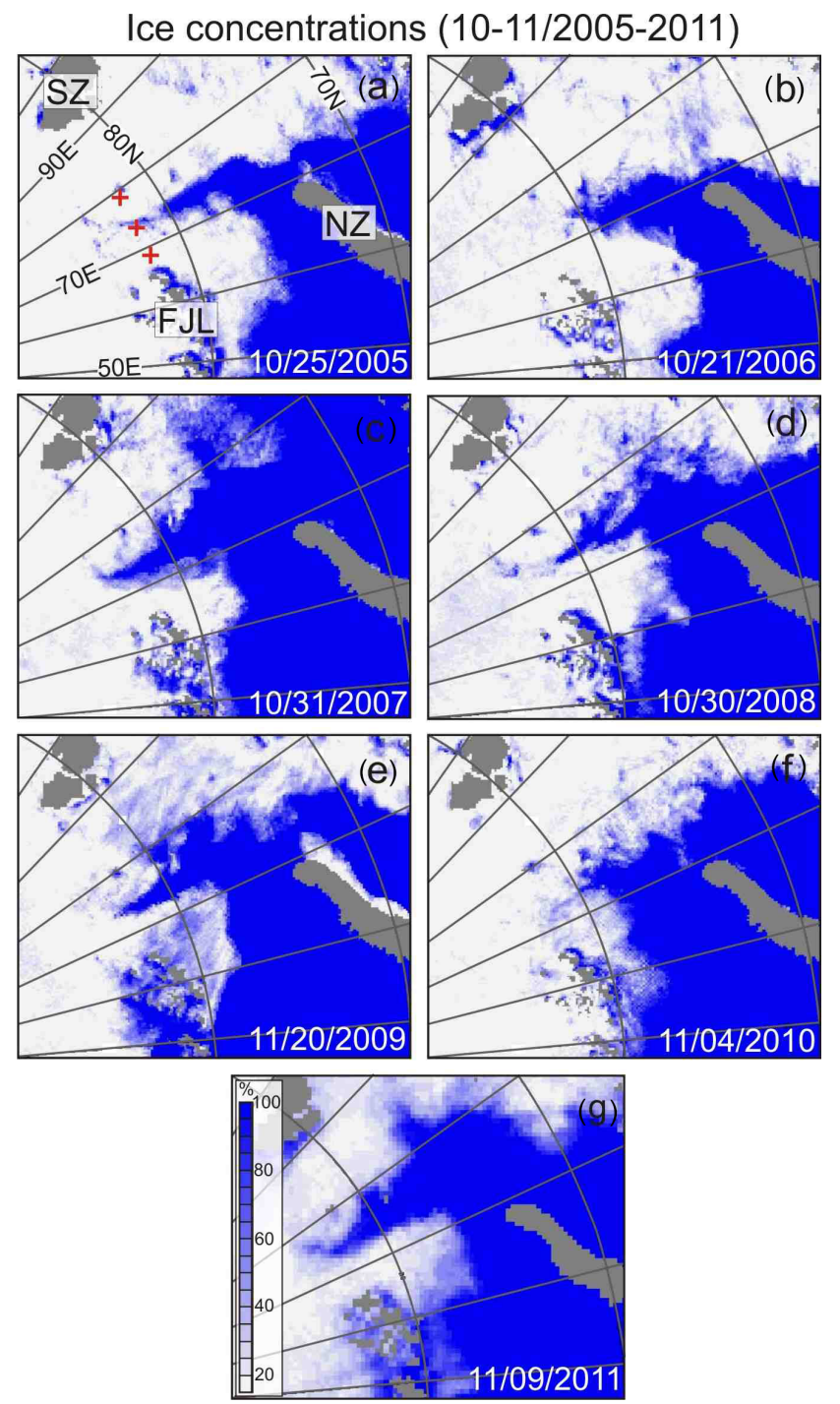

Figure 14. (a-f) The AMSR-E and (g) SSMI sea ice concentrations (\%) in October-November 2005-2011. Crosses in (a) depict locations along $81^{\circ} \mathrm{N}$ where the June-November time series of sea ice concentration shown in Fig. 12 are compiled.

the horizontal density gradient across the ST eastern flank (Figs. 6 and 8). In turn, this gradient is conditioned by the density difference between the SFSBW and the Barents Sea outflow to the Arctic Ocean through the St. Anna Trough.

The deficiencies in our analyses clearly define a necessity for further research in this area to quantify the efficiency of shear instability in facilitating the heat loss from the St. Anna Trough recirculating Fram Strait branch, involving advanced field experiments and further analyses of model simulations.

Acknowledgements. This study was supported by the Canada Excellence Research Chair (CERC) program, the Canada Research Chairs (CRC) program, and the National Sciences and Engineering Research Council of Canada (NSERC) grant RGPIN-2014-03606. 
The 2008-2010 oceanographic observations in the St. Anna Trough were conducted under the working frame of the NABOS project with support from NOAA and NSF, the "System Laptev Sea" project funded through the German BMBF, and project "Arctika" (Russia). The numerical simulations were performed at the DKRZ, Hamburg, Germany, in the frame of the German BMBF project "Nordatlantik" (WP 4.1) and the European Commission FP7 collaborative project "MONARCH-A" (FP7-Space-2009-1 contract 242446). AARI co-authors of this study were supported by the EU FP7 "Arctic Climate Change Economy and Society" (ACCESS) project and RFBR grant 13-05-41443. We acknowledge Lars Kaleschke (University of Hamburg, Germany) for providing the sea ice concentration data through the Integrated Climate Data Center (ICDC) at the University of Hamburg, Germany. Yan Waddington and Torben Klagge have rendered valuable assistance in performing mooring deployment and recovery in the St. Anna Trough.

Edited by: M. Meier

\section{References}

Adcroft, A., Campin, J.-M., Hill, C., and Marshall, J.: Implementation of an atmosphere-ocean general circulation model on the expanded spherical cube, Mon. Weather Rev., 132, 2845-2863, doi:10.1175/MWR2823.1, 2004.

Alexeev, V. A., Ivanov, V. V., Kwok, R., and Smedsrud, L. H.: North Atlantic warming and declining volume of arctic sea ice, The Cryosphere Discuss., 7, 245-265, doi:10.5194/tcd-7-245-2013, 2013.

Årthun, M. and Schrum, C.: Ocean surface heat flux variability in the Barents Sea, J. Marine Syst., 83, 88-98, 2010.

Årthun, M., Eldevik, T., Smedsrud, L. H., Skagseth, Ø., and Ingvaldsen, R. B.: Quantifying the influence of Atlantic heat on Barents Sea ice variability and retreat, J. Climate, 25, 4736-4743, 2012.

Beszczynska-Möller, A., Fahrbach, E., Schauer, U., and Hansen, E.: Variability in Atlantic water temperature and transport at the entrance to the Arctic Ocean, 1997-2010, ICES J. Mar. Science, 69, 852-863, doi:10.1093/icesjms/fss056, 2012.

Boyer, T., Levitus, S., Garcia, H., Locarnini, R. A., Stephens, C., and Antonov, J.: Objective analyses of annual, seasonal, and monthly temperature and salinity for the World Ocean on a $0.25^{\circ}$ grid, Int. J. Climatol., 25, 931-945, doi:10.1002/joc.1173, 2005.

Dewey, R., Muench, R., and Gunn, J.: Mixing and vertical heat flux estimates in the Arctic Eurasian Basin, J. Marine Syst., 21, 199205, doi:10.1016/S0924-7963(99)00014-7, 1999.

Dmitrenko, I. A., Kirillov, S. A., Ivanov, V. V., and Woodgate, R. A.: Mesoscale Atlantic water eddy off the Laptev Sea continental slope carries the signature of upstream interaction, J. Geophys. Res., 113, C07005, doi:10.1029/2007JC004491, 2008a.

Dmitrenko, I. A., Polyakov, I. V., Kirillov, S. A., Timokhov, L. A., Frolov, I. E., Sokolov, V. T., Simmons, H. L., Ivanov, V. V., and Walsh, D.: Toward a warmer Arctic Ocean: Spreading of the early 21st century Atlantic Water warm anomaly along the Eurasian Basin margins, J. Geophys. Res., 113, C05023, doi:10.1029/2007JC004158, 2008b.

Dmitrenko, I. A., Bauch, D., Kirillov, S. A., Koldunov, N., Minnett, P. J., Ivanov, V. V., Hölemann, J. A., and Timokhov, L. A.: Barents Sea upstream events impact the properties of Atlantic water inflow into the Arctic Ocean: Evidence from 2005-2006 downstream observations, Deep-Sea Res. Pt. I, 56, 513-527, 2009.

Dmitrenko, I. A., Kirillov, S. A., Ivanov, V. V., Rudels, B., Serra, N., and Koldunov, N. V.: Modified halocline water over the Laptev Sea continental margin: Historical data analysis, J. Climate, 25, 5556-5565, 2012

Ezraty, R., Girard-Ardhuin, F., and Croizé-Fillon, D.: Sea ice drift in the central Arctic using the $89 \mathrm{GHz}$ brightness temperatures of the advanced microwave scanning radiometr, User's Manual, IFREMER, Brest, France, 2007.

Gammelsrød, T., Leikvin, Ø., Lien, V., Budgell, W. P., Loeng, H., and Maslowski, W.: Mass and heat transports in the NE Barents Sea: Observations and models, J. Marine Syst., 75, 56-69, 2009.

Hanzlick, D. and Aagaard, K.: Freshwater and Atlantic Water in the Kara Sea, J. Geophys. Res., 85, 4937-4942, 1980.

Ivanov, V. V., Alexeev, V. A., Repina, I., Koldunov, N. V., and Smirnov, A.: Tracing Atlantic water signature in the Arctic sea ice cover east of Svalbard, Adv. Meteorol., 2012, 201818, doi:10.1155/2012/201818, 2012.

Kalnay, E., Kanamitsu, M., Kistler, R., Collins, W., Deaven, D., Gandin, L., Iredell, M., Saha, S., White, G., Woollen, J., Zhu, Y., Leetmaa, A., Reynolds, R., Chelliah, M., Ebisuzaki, W., Higgins, W., Janowiak, J., Mo, K. C., Ropelewski, C., Wang, J., Jenne, R., and Joseph, D.: The NCEP/NCAR 40 Year Reanalysis Project, B. Am. Meteorol. Soc., 77, 437-471, 1996.

Kirillov, S. A., Dmitrenko, I. A., Ivanov, V. V., Aksenov, E. O., Makhotin, M. S., and de Quevas B. A.: The influence of atmospheric circulation on the dynamics of the intermediate water layer in the eastern part of the St. Anna Trough, Dokl, Earth Sci., 444, 630-633, 2012.

Koenigk, T. and Brodeau, L.: Ocean heat transport into the Arctic in the twentieth and twenty-first century in EC-Earth, Clim. Dynam., 42, 3101-3120, doi:10.1007/s00382-013-1821-x, 2013.

Kwok, R. and Cunningham, G.: ICESat over Arctic sea ice: estimation of snow depth and ice thickness, J. Geophys. Res., 113, C08010, doi:10.1029/2008JC004753, 2008.

Kwok, R., Cunningham, G. F., Wensnahan, M., Rigor, I., Zwally, H. J., and Yi, D.: Thinning and volume loss of the Arctic Ocean sea ice cover: 2003-2008, J. Geophys. Res., 114, C07005, doi:10.1029/2009JC005312, 2009.

Large, W. G., McWilliams, J., and Doney, S. C.: Ocean vertical mixing: a review and a model with a nonlocal boundary layer parameterization, Rev. Geophys., 32, 363-403, 1994.

Lenn, Y. D., Rippeth, T. P., Old, C. P., Bacon, S., Polyakov, I., Ivanov, V., and Hölemann, J.: Intermittent intense turbulent mixing under ice in the Laptev Sea continental shelf, J. Phys. Oceanogr., 41, 531-547, 2011.

Lien, V. S. and Trofimov, A. G.: Formation of Barents Sea Branch Water in the Northeastern Barents Sea, Polar Res., 32, 18905, doi:10.3402/polar.v32i0.18905, 2013.

Marshall, J., Adcroft, A., Hill, C., Perelman, L., and Heisey, C.: A finite-volume, incompressible Navier Stokes model for studies of the ocean on parallel computers, J. Geophys. Res., 102, 57535766, 1997.

Melling, H., Lake, R. A., Topham, D. R., and Fissel, D. B.: Oceanic thermal structure in the western Canadian Arctic, Cont. Shelf. Res., 3, 233-258, 1984.

Polyakov, I. V., Timokhov, L. A., Alexeev, V. A., Bacon, S., Dmitrenko, I. A., Fortier, L., Frolov, I. E., Gascard, J.-C., Hansen, 
E., Ivanov, V. V., Laxon, S., Mauritzen, C., Perovich, D., Shimada, K., Simmons, H. L., Sokolov, V. T., Steele, M., and Toole, J.: Arctic Ocean warming contributes to reduced polar ice cap, J. Phys. Oceanogr., 40, 2743-2756, 2010.

Polyakov, I. V., Pnyushkov, A. V., Rember, R., Ivanov, V. V., Lenn, Y. D., Padman, L., and Carmack, E. C.: Mooring-based observations of double-diffusive staircases over the Laptev Sea slope, J. Phys. Oceanogr., 42, 95-109, 2012.

Polzin, K. L.: Statistics of the Richardson number: Mixing models and fine structure, J. Phys. Oceanogr., 26, 1409-1425, 1996.

Rudels, B.: Constraints on exchanges in the Arctic Mediterranean - do they exist and can they be of use?, Tellus, 62A, 109-122, doi:10.1111/j.1600-0870.2009.00425.x, 2010.

Rudels, B., Jones, E. P., Anderson, L. G., and Kattner, G.: On the intermediate depth waters of the Arctic Ocean, in: The Polar Oceans and Their Role in Shaping the Global Environment: The Nansen Centennial Volume, edited by: Johannessen, O. M., Muench, R. D., and Overland, J. E., Geophys. Monogr. Ser., 85, AGU, Washington DC, 33-46, 1994.

Schauer, U., Loeng, H., Rudels, B., Ozhigin, V. K., and Dieck, W.: Atlantic Water flow through the Barents and Kara Seas, DeepSea Res. Pt. I, 49, 2281-2298, 2002a.

Schauer, U., Rudels, B., Jones, E. P., Anderson, L. G., Muench, R. D., Björk, G., Swift, J. H., Ivanov, V., and Larsson, A.-M.: Confluence and redistribution of Atlantic water in the Nansen, Amundsen and Makarov basins, Ann. Geophys., 20, 257-273, doi:10.5194/angeo-20-257-2002, 2002b.

Schlichtholz, P.: Influence of oceanic heat variability on sea ice anomalies in the Nordic Seas, Geophys. Res. Lett., 38, L05705, doi:10.1029/2010GL045894, 2011.

Serra, N., Käse, R., Köhl, A., Stammer, D., and Quadfasel, D.: On the low-frequency phase relation between the Denmark Strait and the Faroe-Shetland Channel dense overflows, Tellus A, 62, 530 $550,2010$.
Sirevaag, A. and Fer, I.: Early spring oceanic heat fluxes and mixing observed from drift stations north of Svalbard, J. Phys. Oceanogr., 39, 3049-3069, 2009.

Sirevaag, A. and Fer, I.: Vertical heat transfer in the Arctic Ocean: The role of double-diffusive mixing, J. Geophys. Res., 117, C07010, doi:10.1029/2012JC007910, 2012.

Skagseth, Ø.: Recirculation of Atlantic Water in the western Barents Sea, Geophys. Res. Lett., 35, L11606, doi:10.1029/2008GL033785, 2008.

Skagseth, Ø., Furevik, T., Ingvaldsen, R. B., Loeng, H., Mork, K. A., Orvik, K. A., and Ozhigin, V.: Volume and heat transports to the Arctic Ocean via the Norwegian and Barents Seas, in: Arctic Subarctic Ocean Fluxes: Defining the Role of the Northern Seas in Climate, edited by: Dickson, R., Meincke, J., and Rhines, P., Springer, New York, 45-64, 2008.

Smith, W. H. F. and Sandwell, D. T.: Global seafloor topography from satellite altimetry and ship depth soundings, Science, 277, 1957-1962, 1997.

Spreen, G., Kaleschke, L., and Heygster, G.: Sea ice remote sensing using AMSR-E $89 \mathrm{GHz}$ channels, J. Geophys. Res., 113, C02S03, doi:10.1029/2005JC003384, 2008.

Steele M. and Morison J.: Hydrography and vertical fluxes of heat and salt northeast of Svalbard in autumn, J. Geophys. Res., 98, 10013-10024, 1993.

Stefan, J.: Über die Theorie der Eisbildung, insbesondere über Eisbildung im Polarmeere, Annalen der Physik und Chemie, Wiedemann-Annalen, 42, 269-286, 1891 (in German).

Sundfjord, A., Fer, I., Kasajima, Y., and Svendsen, H.: Observations of turbulent mixing and hydrography in the marginal ice zone of the Barents Sea, J. Geophys. Res., 112, C05008, doi:10.1029/2006JC003524, 2007. 